\title{
A Review of Bioremediation and Natural Attenuation of MTBE
}

\author{
Lawrence C. Davis and Larry E. Erickson \\ Departments of Biochemistry and Chemical Engineering, Kansas State University, Manhattan, KS 66506; Idavis@ksu.edu (for \\ correspondence)
}

Published online in Wiley InterScience (www.interscience.wiley.com). D0I 10.1002/ep.10028

Methyl tert-butyl ether (MTBE) has been the focus of much attention because it is used in large amounts and was reportedly relatively recalcitrant to bioremediation or natural attenuation. Beginning with a few papers a decade ago, evidence has been presented that, in fact, under suitable conditions it is amenable to bioremediation. Many species from widely disparate microbial genera are able to consume it either as a sole carbon source or as a cometabolite. Optimal conditions differ from site to site. Both aerobic and anaerobic conditions may permit MTBE degradation, with a range of electron acceptors, from oxygen through $\mathrm{Fe}(I I I), \mathrm{Mn}(I V)$, sulfate, nitrate, and methanogenesis. MTBE metabolism in the vadose zone can be highly active. The published literature suggests that natural populations are adapting to MTBE, and reported rates of biodegradation appear to be larger in the more recent literature. Plants may serve as efficient conduits to withdraw MTBE from the wet subsurface, releasing it to the atmosphere or the vadose zone, where it may be metabolized or diffuse into the atmosphere where it is quickly photodegraded. The major remaining issues are the time required to attain specified criteria of cleamup or whether augmentation is necessary for effective remediation. (c) 2004 American Institute of Chemical Engineers Environ Prog, 23: 243-252, 2004 tion

Keywords: MTBE, bioremediation, phytoremedia-

\section{INTRODUCTION}

MTBE, more formally methyl tert-butyl ether, has been extensively used as an octane booster and oxygenate additive in reformulated gasoline in the United States. With MTBE being distributed nationwide, the potential for contamination of soil and groundwater is substantial. Efforts to develop strategies for cleanup have produced a large number of publications, a selec-

(C) 2004 American Institute of Chemical Engineers tion of which are discussed below [1-60]. MTBE has certain advantages over ethanol in the behavior of gasoline blends to which it is added, and it is efficiently produced from iso-butylene. Current production (2003) of MTBE is over 200,000 barrels per day $\left(\sim 8 \times 10^{6} \mathrm{~L}\right)$ in the United States and U.S. usage is about $1 / 3$ greater [12].

Physical and organoleptic properties of MTBE make it a challenge to deal with effectively. Unlike most gasoline constituents, MTBE is highly soluble in water. At room temperature its solubility is about $50 \mathrm{~g} / \mathrm{L}, 20$ times greater than that of BTEX, the most soluble gasoline constituents (benzene, toluene, xylenes, and ethyl benzene). As discussed by Kinner [30] it also partitions strongly from air to water. The dimensionless Henry's Law constant is in the range of 0.01 to 0.04 , depending on temperature [10], whereas that of benzene is about 0.2. Thus MTBE is more likely to dissolve in water and less likely to volatilize from gasoline or water to air than is the case for other gasoline constituents.

Some of the important physical and chemical properties of MTBE and BTEX compounds are shown in Tables 1 and 2. Because of its small Henry's constant, MTBE is expensive to remove from water by aeration. Removal using adsorption is expensive because the quantity that adsorbs to activated carbon is relatively small based on the small values of the octanol/water partition coefficient and sorption coefficient. Keller et al. [27] evaluated four physicochemical treatment technologies and reported estimated costs associated with each technology. When no air treatment is required, air stripping is the lowest-cost technology for high flow rates, whereas hollow-fiber membranes are cost effective for low flow rates. Granular activated carbon is most cost effective if air treatment costs are included. Advanced oxidation processes are the most expensive of the four options.

Although health effects of low-level MTBE contam- 
Table 1. Physical and chemical properties of MTBE (from [54]).*

\begin{tabular}{ll}
\hline Physical state & Colorless liquid \\
Molecular formula & $\mathrm{C}_{5} \mathrm{H}_{12} \mathrm{O}$ \\
Molecular weight & 88.15 \\
Melting point & $-109^{\circ} \mathrm{C}$ \\
Boiling point & $55.2^{\circ} \mathrm{C}$ \\
Water solubility & $51 \mathrm{~g} / \mathrm{L} @ 25^{\circ} \mathrm{C}$ \\
Density & $0.74(\mathrm{~g} / \mathrm{mL}) @ 25^{\circ} \mathrm{C}$ \\
$K_{\mathrm{oc}}$ & $12.3 ; 11.0$ (estimated) \\
log $K_{\text {ow }}$ & 1.24 \\
Vapor pressure & $245 \mathrm{mmHg} @ 25^{\circ} \mathrm{C}$ \\
Henry's law constant & $0.02 \mathrm{at} 25^{\circ} \mathrm{C}$ \\
Odor threshold & $15-40 \mathrm{ppb}$ \\
Taste threshold & $40-140 \mathrm{ppb}$ \\
Volume in gasoline & $\mathrm{Up} \mathrm{to} 15 \%$ \\
Water solubility when in & \\
\multicolumn{1}{l}{ gasoline } & $\mathrm{Up}$ to $5100 \mathrm{ppm}$ \\
\hline
\end{tabular}

Similar values are presented by Keller et al. [27], Jacobs et al. [24], and Seagren and Becker [45].

ination are uncertain and disputed (see [13]), it has a potent taste impact in water at levels of $10-30 \mu \mathrm{g} / \mathrm{L}$ (ppb). Thus even small spills of MTBE are detectable, and the USEPA [49] issued a health advisory recommending that drinking water levels be kept below $20-40 \mu \mathrm{g} / \mathrm{L}$. This would provide a very large safety margin compared to known biological effects. Many states have implemented regulations on MTBE contamination of water and a number have banned its use in gasoline. Through the year 2000, 38 states had action levels, cleanup levels, or drinking water standards for MTBE [37].

The drinking water levels varied but were all below $250 \mu \mathrm{g} / \mathrm{L}$. As of March 2003, restrictions or outright bans were pending in 16 states. Five states proposing bans or severe restriction depend on MTBE for oxygenates and account for $45 \%$ of MTBE use nationwide [12]. Thus if implemented, these restrictions could markedly reduce new incidents of MTBE contamination of groundwater.

One liter of MTBE/ha could contaminate all the yearly rainfall on that area to a level of about $100 \mathrm{ppb}$ (assuming $1 \mathrm{~m} / \mathrm{yr}$ rain). Avoiding such contamination in areas where there is a lot of reformulated gasoline use has proven challenging. When MTBE constitutes
$10-15 \%$ of the gasoline, containment systems have to maintain nearly perfect efficacy to avoid some contamination of groundwater. This has been a particular issue in California, which consumes a large fraction of all U.S. MTBE, although the expected magnitude of the problem is debated $[26,33]$.

Given the widespread nature of MTBE contamination and the intense efforts to remediate it, a large number of studies have been published that detail an extensive amount of research. Prince [40] provided an excellent critical summary of what was known about microbial degradation of MTBE. More recently, Fayolle et al. [14], Fiorenza et al. [16], and Seagren and Becker [45] provided reviews that describe some of the additional progress that has occurred. Fayolle et al. [14] examined the broader issues of remediating other oxygenates such as tert-amyl methyl ether and $t$-butyl alcohol. Fiorenza et al. [16] considered the distribution of contamination problems, the nature of plumes, and examples of natural attenuation. Seagren and Becker reviewed the natural attenuation of BTEX and MTBE [45]. Here we focus on a limited selection of recent papers (since 2000) to show how prospects for bioremediation of MTBE have improved.

\section{THE CHALLENGE OF DEGRADING MTBE}

Because MTBE is a highly hindered ether, the initial step of hydrolysis to the alcohols is difficult. In addition, the tert-butyl group is not easily metabolized by many organisms. Initial experience with MTBE contamination suggested that there were far fewer organisms able to effectively degrade it than there were for gasoline constituents such as BTEX. Thus initial efforts to remediate MTBE contamination focused on traditional remediation strategies such as pump and treat, air sparging, or chemical oxidation in situ. Kinner [30] offers a useful summary of some strategies implemented before 2001. For very dispersed, low-level contamination these techniques prove to be very costly per unit of contaminant removed, even though MTBE is amenable to the above-mentioned removal strategies that are usable for other gasoline constituents [2]. Odencrantz [38] described several case studies in which very extensive MTBE plumes were monitored, with little evidence for intrinsic remediation. One interesting implication is that there may be many BTEX spills that pass undetected because of intrinsic remediation, whereas the accompanying MTBE leaves a clearly detectable plume.

Table 2. Physical and chemical properties of BTEX compounds at $25^{\circ} \mathrm{C}$.*

\begin{tabular}{lcccc}
\hline Property & Benzene & Toluene & $\boldsymbol{p}$-Xylene & Ethyl benzene \\
\hline Molecular weight & 78.11 & 92.13 & 106.16 & 106.16 \\
Solubility, g/L & 1.8 & 0.5 & 0.2 & 0.2 \\
log $K_{\text {ow }}$ & 2.1 & 2.7 & 3.2 & 3.2 \\
Vapor pressure, mmHg & 95 & 28 & 9 & 10 \\
Henry's law constant, dimensionless & 0.22 & 0.26 & 0.31 & 0.32 \\
\hline
\end{tabular}

From references [45] and [60]. 


\section{MTBE CLEANUP STRATEGIES AND COST}

Current cleanup technologies for MTBE still remain much the same as those of 5 years ago. At a recent meeting [36] there were presentations on in situ chemical oxidation (permanganate and persulfate), ozonation, Fenton's reagent, in-well air stripping, and advanced oxidation combined with granulated activated charcoal (GAC) treatment. However, there was also consideration of bioremediation strategies including fluidized bed bioreactors, oxygen infusion, propanestimulated cometabolism, oxygen-release compound, biostimulation of indigenous microorganisms, and use of a biobarrier, iron, and humates.

Wilson et al. [50] presented information on the cost associated with the remediation of sites contaminated with MTBE and other petroleum compounds. The average cost of 311 sites was $\$ 200,827$; however, the average cost was $\$ 414,273$ for the 32 sites that were affecting drinking water wells or supplies. The average values of monitored natural attenuation costs were $\$ 74,000$ in Tennessee and $\$ 113,574$ in Texas. In both states, the cost of monitored natural attenuation was less than each of the other alternative technologies that had been used at other field sites. Bioremediation rates are important in monitored natural attenuation.

\section{BIOREACTORS ARE EFFECTIVE EX SITU}

Kharoune et al. [29] developed a bioreactor with an inoculum from contaminated soil. A biomass of $1 \mathrm{~g}$ dry wt/L accumulated and was able to consume 99\% of an input of $80 \mathrm{mg} / \mathrm{L}$ MTBE with a hydraulic retention time of $24 \mathrm{~h}$. Similar results were obtained by Wilson et al. [51], with a bioreactor depleting $150 \mathrm{mg} / \mathrm{L}$ MTBE with a 4-day residence time. The biomass was about $1 \mathrm{~g} / \mathrm{L}$, indicating somewhat less active culture than that of Kharoune et al. The starter culture for this reactor was obtained from several sources and no particular organisms were identified.

A cometabolic reactor was developed by Dupasquier et al. [11] using a pentane-oxidizing Pseudomonas aeruginosa. It serves as a biofilter for MTBE vapors, but not for MTBE in water. The specific activity was relatively low and pentane was required as the cosubstrate. Fortin and Deshusses described a biotrickle filter to treat MTBE vapors and established a stable microbial consortium that mineralized $100 \mathrm{mg} / \mathrm{L}$ MTBE within a day in a liquid culture [17]. The estimated specific activity was in the range of $240 \mathrm{mg}$ MTBE per gram dry wt culture per day, suggesting a somewhat more active culture than that of Kharoune et al. [29]. Many other compounds could be metabolized by the consortium and evidently one or more of these supported growth of the MTBE degrading organisms, because no single strain able to degrade MTBE could be isolated from the consortium.

\section{ISOLATED ORGANISMS CAN DEGRADE MTBE}

Mo et al. [34] identified three pure cultures of single species able to degrade MTBE, albeit at very modest rates. Genera represented were Rhodococcus, Arthrobacter, and Methylobacterium. Other microbial species including bacteria and fungi were described shortly thereafter. Numerous consortia have also been reported. The earliest report of an effective bacterial consortium was published in 1994 by Salanitro et al. and a presumably different consortium was identified 2 years later by Cowan and Park. Prince [40] provided a thoroughly documented review of examples for consortia and pure cultures described to that time. (See his paper for citations of those earlier studies.)

Bruns et al. [9] reported on a compost biofilter from which a strain PM1 was isolated [19]. Bruns et al. found that PM1 was the dominant organism when measured by molecular (PCR)-based methods, although the most abundant microbial isolates from the cultures were more rapidly growing yellow and white colonies of organisms unable to metabolize MTBE. The strain PM1, which can grow on MTBE as a sole carbon source, produced pinpoint cream colonies under standard plate culture conditions. Molecular characterization by ribosomal RNA intergenic transcribed spacer (ITS) indicated that PM1 is in the general $\beta$-proteobacteria subgroup including Leptothrix and Rubrivivax. Hanson et al. [19] showed that it converted MTBE to $\mathrm{CO}_{2}$ and cell biomass with a yield of $0.18 \mathrm{mg}$ cells/mg MTBE. The organism was active with MTBE concentration as high as $500 \mathrm{mg} / \mathrm{L}$ and fully degraded low levels of $\operatorname{MTBE}(20 \mathrm{mg} / \mathrm{L})$.

Hatzinger et al. [20] observed biodegradation of MTBE by a pure culture of a strain identified as $H y$ drogenophaga flava ENV 735. This organism grew well with hydrogen as an energy source. Growth was slow on pure MTBE and was stimulated by addition of yeast extract. Cells grown on higher levels of yeast extract had constitutive MTBE degrading ability, but degradation of $t$-butyl alcohol was inducible. In addition, the metabolism of $t$-butyl alcohol responded differently to addition of oxidase inhibitors, indicating that there are two independent oxidase systems for the limiting steps of MTBE and $t$-butyl alcohol degradation. The organism was applied to MTBE biotreatment as described by Steffan et al. [47]. A variant organism with reduced adhesion has been tested for its ability to migrate within aquifer sediments, and the effect of surfactant on mobility of the wild-type has been tested [48]. The variant organism is apparently a subpopulation of the typical culture. Many surfactants proved toxic but Tween 20 enhanced mobility in sand columns.

A methylotrophic bacterium, Mycobacterium austroafricanum IFP 2012, efficiently degraded MTBE with a high yield of biomass of $0.44 \mathrm{~g}$ per $\mathrm{g}$ MTBE consumed [18]. The specific rate of degradation of MTBE by resting cells previously grown on $t$-butyl alcohol was about $1.4 \mathrm{~g}$ MTBE per g dry wt per day, but the doubling time of cells grown with $t$-butyl alcohol was rather long, about a day. With MTBE as growth substrate there was no exponential phase of growth; $t$-butyl alcohol accumulated during the initial stages of MTBE use and then was in turn consumed.

Kern et al. [28] used molecular microbial community analysis techniques to study MTBE degraders from a contaminated aquifer in Montana. An active consortium was isolated and from it two MTBE degraders, Rhodococcus koreensis and Pseudomonas Ant9, were obtained. However, both required propan-2-ol as a cosubstrate and both strains were lost from the 
consortium on repeated subculturing. Growth of the consortium was stimulated by spent culture medium, indicating that growth factors might be produced and excreted by some members.

Thus, there are multiple species naturally present and able to use MTBE, but not necessarily under simple conditions. Rather different conditions permit or enhance MTBE degradation.

\section{SOME MTBE DEGRADERS ARE ACTIVE UNDER "NATURAL" CONDITIONS}

Most studies in the laboratory or field indicate a primarily aerobic degradation process for MTBE, but there are reports implying degradation under methanogenic or other anaerobic conditions [6, 15, 23, 45, 52]. The study of Finneran and Lovley [15] showed that humic substances were important as mediators for the facilitated degradation of MTBE using reduction of Fe(III) as the oxidant. Hurt et al. [23] inferred the anaerobic degradation of MTBE from the presence of $t$-butyl alcohol and disappearance of MTBE from the middle of a plume having a high concentration of BTEX. Wilson et al. [52] showed that MTBE was removed only after BTEX, in laboratory microcosms constructed from material obtained in a contaminated plume. Bradley et al. [5-7] examined several electron acceptors, under anoxic conditions, as discussed below.

The paucity of examples of complete in situ MTBE degradation in earlier years and the much more general finding of effective degradation more recently may reflect the intensity of research effort, or the enhancement of microbial populations when MTBE became more widespread in the environment. Bradley et al. [5] first found MTBE degradation in streambed sediments near an MTBE contaminated site. Later work by the same group [8] indicated that the potential to degrade MTBE is widespread. They identified activity at 11 widely separated sites with 15-66\% mineralization of MTBE occurring in 7 weeks in microcosms. A history of MTBE exposure did not seem to be necessary for the activity to be present. Sandy sediments were more active than those with a high clay and silt content, but organic matter content was only weakly related to activity. Because the microcosms were incubated static but aerobic, diffusion of oxygen to active microbes could have been dependent on porosity of the sediment, and diffusion in turn might have limited the activity.

Bradley et al. [6] also showed that MTBE degradation could occur in microcosms with streambed organisms under denitrifying conditions. One sediment was from MTBE contaminated waters and another from an uncontaminated site. Both were able to mineralize added MTBE when nitrate was available. Under methanogenic conditions (no added nitrate) the undesirable intermediate $t$-butyl alcohol was produced, whereas relatively little MTBE was transformed during the period of the incubation, and there was no mineralization of the MTBE.

Bradley et al. [9] documented the dependency of MTBE degradation rate and extent on the redox state of the system for three sandy sediments from different locations, only one of which was known to have been exposed to MTBE. When there was an electron acceptor to avoid methanogenesis, mineralization occurred, rather than production of $t$-butyl alcohol. Sulfate, $\mathrm{Fe}(\mathrm{III})$, and Mn(IV) were less effective than nitrate or oxygen. Results varied from one site to another for particular electron acceptors.

In other work, Landmeyer et al. [31] observed that enhancement of MTBE degradation in a gasoline plume depended on introduction of oxygen, either by rainfall recharge or by deliberate addition of an oxygen-releasing compound. When gasoline is released with MTBE, degradation of hydrocarbons rapidly consumes available oxygen, resulting in MTBE remaining present even as the hydrocarbons disappear. If the MTBE contaminated water comes into the presence of either nitrate or oxygen and in absence of BTEX, MTBE may be consumed.

Kane et al. [25] examined aquifer materials in the vicinity of four leaking underground storage tanks in California. The microcosms that they studied were initially oxygen limited. For two of the sites, aerobic incubation resulted in effective degradation of MTBE, whereas for two others it did not. Thus, appropriate organisms or conditions may not be present at all sites. Where there was activity, organisms similar to a known MTBE degrader, strain PM1, were found to be present.

Schirmer and Barker [43] described a long-term study at the Borden aquifer in Ontario, Canada, where a known amount of MTBE was introduced, along with gasoline constituents, to produce a plume below the water table. Chloride was introduced as a conservative tracer. After about 6 years, only 3\% of the MTBE mass remained, corresponding to a half-life of about 1 year. The BTEX of gasoline was more rapidly degraded, showing near total disappearance in the first 16 months of the study. Recently Schirmer et al. [44] reported laboratory evidence with microcosms, to show that MTBE degradation occurs in aquifer materials from that site. Three microcosms showed MTBE disappearance, but only after a lag of 189-300 days. Several other microcosms, prepared at the same time with a variety of amendments, failed to show MTBE degradation. Thus the occurrence of MTBE degradation seemed to be sporadically present at the site and factors determining expression of that activity remain to be identified.

A study from Europe reports that only one aquifer, out of four MTBE-contaminated aquifers tested, was positive for intrinsic MTBE degradation capability [35]. However, all four could degrade benzene. The MTBE degrader was not identified.

Zoeckler et al. [57] searched for intrinsic bioremediation of MTBE in aquifer sediments in the vicinity of a gasoline-contaminated aquifer in Virginia. A sample from upgradient of the contamination showed toluene degradation but no MTBE loss. A sample from downgradient showed MTBE loss but at a lesser rate than that of a sample from the source area. The more active source area sample degraded MTBE with an apparent first-order rate of about $0.06 /$ day, decreasing the input concentration from 4.8 to $1.5 \mathrm{mg} / \mathrm{L}$ in about 15 days. Aquifer material was diluted to maintain aerobic microcosms with $5 \mathrm{~g}$ material added to $10 \mathrm{~mL}$ water. Thus initial rates were in the range of $1 \mathrm{mg} / \mathrm{kg}$ material/day. 
The original source area sediments contained variable levels of MTBE from 1 to $>50 \mathrm{mg} / \mathrm{L}$. In situ at the source area, the MTBE degradation may have been oxygen limited because there was a significant amount of petroleum hydrocarbon present.

\section{DEGRADATION IS DOCUMENTED IN SITU}

Bioremediation and natural attenuation have been investigated at a number of field sites [1, 32, 39, 45, 52, 60]. Significant differences have been found from site to site with respect to the rate of biodegradation. Values range from the rate being so small that biodegradation is not measurable to clear evidence of biodegradation. Peargin [39] found 15 sites with no observed bioremediation and eight sites with a significantly larger remediation rate. Robb and Moyer [41] also found significant differences at the two sites described in their work. These differences appear to be attributable to site characteristics that affect rates of mass transfer. Disappearance of MTBE appears to be attributable to volatilization and biodegradation so the natural attenuation process may require several years because of mass transfer limitations. Oxygen transfer rates are generally greater in unsaturated soil where gas-phase diffusion contributes to mass transfer. The slowest mass transfer rates are in the saturated zone where there is little or no convective flow.

First-order rate constants as large as 0.4 per day have been observed under aerobic conditions [19]. Under anaerobic conditions values are as large as 0.01 per day [52]. These values correspond to half times of 1.7 and 69 days, respectively. Because rates at most field sites are less than these values, remediation times may often exceed one year where natural attenuation is used and biodegradation is one of the processes that contributes to disappearance of MTBE.

\section{AUGMENTATION SPEEDS ACTIVITY WITHIN AQUIFERS}

Laboratory studies of water and sediments from Vandenberg Air Force Base, California were used to try to identify suitable geochemical conditions for aerobic MTBE degradation [53]. Stimulation of cometabolism and stimulation of indigenous organisms were considered, along with the possibility of introducing an active strain. However, indigenous activity was associated with the preexisting presence of strain PM1-like organisms [22]. Supplementation with oxygen was sufficient to increase MTBE degradation, even though the organism was generally not detectable before that time by molecular techniques. Increased oxygenation of an anaerobic MTBE plume resulted in MTBE degradation at the same site [53]. Once an effective treatment zone was established, increased MTBE was effectively degraded at input levels up to $2 \mathrm{mg} / \mathrm{L}$.

Recent work from Scow's group [22] documented the behavior of strain PM1, within an MTBE plume at Vandenberg Air Force Base. At that location the numbers of PM1 type organisms were estimated, by quantitative PCR, to range from $10^{3}$ to $10^{4}$ per $\mathrm{mL}$ under oxygen stimulated conditions, although the organism was nearly undetectable without oxygen stimulation. In situ it was probably oxygen limited. When a little MTBE $(10 \mu \mathrm{g} / \mathrm{L})$ was added in oxygen-stimulated mi- crocosms, cell numbers rose to $10^{5}$ per $\mathrm{mL}$. In field studies, numbers of organisms rose in proportion to added MTBE.

Salanitro et al. [42] described the development of a biobarrier at the U.S. Navy Environmental Test Site, Port Hueneme, CA. Earlier they had used a mixed culture of MTBE degrading organisms, whereas in their more recent work they used an isolated organism identified as a Rhodococcus. Oxygenation was ensured by intermittent sparging with air or pure oxygen. Within 9 months, levels of MTBE declined from about $1 \mathrm{mg} / \mathrm{L}$ to a few $\mu \mathrm{g} / \mathrm{L}$ in the biobarrier zone. The identity of the active MTBE degraders was not confirmed but was assumed to be the same as the introduced strain.

Propane biostimulation was tested at Port Hueneme, CA. Using deuterated MTBE and groundwater tracers to monitor the process, it was found insufficient to meet the state's treatability criteria [49].

A cometabolic system has been field-tested [3] using cyclohexane as carbon source with added oxygen. The MTBE concentration declined $80 \%$ over the time of treatment. Stimulation of MTBE degradation by supplying oxygen, nutrients, and strain PM1 as an MTBE degrader was successful [46]. Levels of MTBE were reduced as much as $85 \%$ within a year at a location in Montana that showed no prior evidence for the presence of strain PM1. However, naturally occurring MTBE degraders were also present.

\section{MTBE DEGRADATION CAN OCCUR IN THE VADOSE ZONE}

In this laboratory, studies of MTBE have been conducted over a number of years, with sandy soil obtained near the Kansas River adjacent to the closed Riley County landfill. Zhang [54] and Zhang et al. [55, 56] examined MTBE losses by groundwater movement and volatilization through the vadose zone for six channels, $10 \times 65 \times 110 \mathrm{~cm}$, packed with the sandy soil. In five channels with growing alfalfa plants, losses of MTBE to the atmosphere were significantly greater than those for an unplanted channel. Disappearance of MTBE was also slightly greater for four channels that had been inoculated with strains of Rhodococcus (two channels) or Arthrobacter (two channels) obtained from C. Kulpa; however, there is not sufficient replication to show that these differences are statistically significant. These were two of the three strains reported by Mo et al. [34]. (The other strain derived in their study was a Methylobacterium.) The duration of this first experiment $[54,56]$ was a few months and there was no clear evidence for a large fraction of the MTBE not accounted for through water outflow or surface volatilization. Obtaining reliable mass balances from surface gas flux rates is difficult. Zhang et al. [55] monitored MTBE flux through plants in this experiment before adaptation to MTBE occurred and found a considerable fraction of the total volatilization loss was by the plants. A portion of MTBE was transpired from the leaves but a larger fraction diffused from roots within the vadose zone and from the relatively small diameter alfalfa stems. For this experiment MTBE was introduced with the water for 83 days and washed out for 96 days.

Microcosms were prepared from vadose zone soil 
from all six channels during the washout period and were incubated with MTBE. After 5 months there was definite evidence for MTBE disappearance in some microcosms. Repeated feeding of the same microcosms, which are kept just moist, has resulted in activities up to $10 \mathrm{mg}$ per $\mathrm{kg}$ soil per day. These have remained active with just MTBE feeding and occasional aeration, by opening the bottle for a few minutes, for more than 3 years. This shows that there is no rapid buildup of substances that might be inhibitory to MTBE degradation. When soil samples were incubated under saturated conditions there was no evidence for MTBE disappearance. One microcosm prepared fully saturated became highly methanogenic but showed no evidence of MTBE disappearance.

More recently, the possibility of microbial adaptation in the vadose zone has been explored. Two channels were exposed to MTBE in the inflowing groundwater, with a water table maintained about $20 \mathrm{~cm}$ from the bottom of the channels. In this study only the latter half of each channel had plants in place. Initial MTBE levels in the input water were $100 \mu \mathrm{L} \mathrm{MTBE} / \mathrm{L}$ water $(\sim 74 \mathrm{mg} / \mathrm{L})$. Significant fluxes of MTBE from the soil surface were not observed except in the planted area, after 8 months' exposure. The concentration of MTBE in the input water was increased to $250 \mu \mathrm{L} / \mathrm{L}$ and surface gas fluxes were observed after 2 months, but only small amounts, and only in the planted area. After 8 months they were negligible. Finally the input concentration was increased to $1 \mathrm{~mL} / \mathrm{L}(\sim 740 \mathrm{mg} / \mathrm{L})$. Once again there was a period of adaptation when MTBE flux was readily measurable followed by return to a no flux condition. After 3 months the rate of MTBE transport at the surface was only about $10 \%$ of the rate predicted from water usage. By 8 months there was negligible surface flux.

The experimental setup is such that a fully saturated zone is present $(\sim 20 \mathrm{~cm})$ with a relatively short retention time for that portion of water that flows through without vertical movement (1-2 days). Sampling of both inlet and outflow water gives no indication that there is degradation of MTBE in the groundwater during that short residence time. The available oxygen in the inlet water would be sufficient for only a minute fraction of the total MTBE to be fully mineralized $(\sim 50$ $\mu \mathrm{mol}$ of $8.4 \mathrm{mmol} / \mathrm{L}$ at the highest tested concentration).

Soil samples taken from the channels at various periods during this prolonged treatment regimen show the ability to consume MTBE aerobically. After 9 months of MTBE exposure at $100 \mu \mathrm{L} / \mathrm{L}$, samples were taken at three depths in both planted and unplanted regions. Activities were in the range of $1 \mathrm{mg} \mathrm{kg}^{-1}$ day $^{-1}$ MTBE consumption (Table 3 ). This activity is sufficient to degrade the calculated vertical flux of MTBE within the vadose zone.

Rates in soil taken from 7.5 to $15 \mathrm{~cm}$ below the surface are $6-8.5 \mathrm{mg} \mathrm{kg}^{-1}$ day $^{-1}$ after 18 months of channel treatment at the highest MTBE level $(1 \mathrm{~mL} / \mathrm{L})$. Activities at the $15-22 \mathrm{~cm}$ depth are somewhat lower, about $5 \mathrm{mg} \mathrm{kg}^{-1}$ day $^{-1}$. This ex situ estimate is about right to account for all of the MTBE that is in the water that is currently consumed, whereby $>250 \mathrm{~mL}$ water
Table 3. MTBE degradation rates with vadose zone soil samples.

\begin{tabular}{ccc}
\hline Location* & $\begin{array}{c}\text { Planted** } \\
\left.\text { (mg kg }^{-\mathbf{1}} \mathbf{d a y}^{\mathbf{- 1}}\right)\end{array}$ & $\begin{array}{c}\text { Unplanted } \\
\text { (mg kg }^{-\mathbf{1}} \mathbf{d a y}^{-\mathbf{1}} \text { ) }\end{array}$ \\
\hline Channel 1 & & \\
$0-7.5 \mathrm{~cm}$ & 0.6 & 0.8 \\
$7.5-15 \mathrm{~cm}$ & 2.5 & 0.7 \\
$15-22 \mathrm{~cm}$ & 1.7 & 1.0 \\
Channel 2 & & \\
$0-7.5 \mathrm{~cm}$ & 0.9 & 0.5 \\
$7.5-15 \mathrm{~cm}$ & 2.1 & 0.7 \\
$15-22 \mathrm{~cm}$ & 1.0 & 1.0 \\
\hline
\end{tabular}

Samples were taken with a cork borer $(\sim 1 \mathrm{~cm})$ at four positions along planted or unplanted portion of the channel and pooled for analysis. Indicated depths are approximate, assuming that a complete core is obtained at each depth. Total sample mass varied from 18 to $32 \mathrm{~g}$, and soil moisture fraction varied from 0.07 to 0.19 . For the topmost samples (18-23 g), moisture was augmented by adding $0.5 \mathrm{~mL}$ water. Each pooled sample was incubated in a $125-\mathrm{mL}$ serum bottle with a serum stopper.

**Rates were determined with known amounts of MTBE $(0.57 \mathrm{mg})$ added to each bottle. Values shown are per kilogram of dry soil.

passes vertically through $<50 \mathrm{~kg}$ soil/day. A portion of the water enters the plants, carrying some MTBE with it, but this can account for only a small fraction of the loss. There is no detectable surface loss by volatilization.

The above experiment does confirm that the vadose zone can serve as a highly effective sink for MTBE, when adapted organisms are present. The identity of the active organisms has not yet been determined in this experiment. The concentrations of MTBE being metabolized in this vadose zone system considerably exceed concentrations studied by other groups with organisms in liquid culture with soils from aquifers or sediments. Routine feeding of the microcosms uses about $2 \mathrm{mg}$ MTBE for $4-5 \mathrm{~mL}$ water in the microcosm, giving concentrations in the range of $400-500 \mathrm{ppm}$ in the aqueous phase. The inlet water of the channels being studied contains $740 \mathrm{mg} / \mathrm{L}$ MTBE. Its concentration declines through the vadose zone and the vertical soil substrate profile presumably is indicative of oxygen diffusion to the sites of reaction. Thus we have established a very effective passive bioreactor and demonstrated that vadose zone soil could serve as a large sink for MTBE. The work of Landmeyer et al. [31] indicates that a similar situation exists in natural settings, such as streambeds, where anaerobic water with MTBE is seeping into the aerobic stream from groundwater.

The extent to which the vadose zone functions in MTBE removal in the natural environment has not been examined. In locations with fluctuating water tables and intermittent recharge surrounding shallow contam- 
Table 4. Summary of MTBE degradation rates.

\begin{tabular}{|c|c|c|c|}
\hline $\begin{array}{l}\text { First order } \\
\text { rate } \\
\text { constant, } \\
\text { days }^{-1}\end{array}$ & $\begin{array}{c}\text { Specific } \\
\text { degradation } \\
\text { rate, mg } \\
\text { MTBE/g } \\
\text { cells day }{ }^{-1}\end{array}$ & $\begin{array}{l}\text { Degradation } \\
\text { rate, mg } \\
\text { MTBE/kg } \\
\text { soil day }{ }^{-1}\end{array}$ & Reference \\
\hline & 79 & & [29] \\
\hline & 37 & & [51] \\
\hline & 240 & & [17] \\
\hline & 1400 & & [18] \\
\hline 0.06 & & 1 & [57] \\
\hline 0.1 & & & [4] \\
\hline 0.01 & & & [52] \\
\hline 0.005 & & & [46] \\
\hline 0.3 & & & [22] \\
\hline 0.3 & & & [25] \\
\hline 0.4 & & & [19] \\
\hline $0.001-0.1$ & 130-3000 & & [60] \\
\hline
\end{tabular}

ination, as from gasoline spills, it could be a significant sink.

Table 4 provides a summary of MTBE biodegradation rates. In some cases, rates have been estimated from the data that are presented in the original work. These results show that biodegradation occurs at reasonable rates under aerobic conditions when microbial populations that can grow on MTBE are present. By providing nutrients, oxygen, and organisms that are adapted to grow on MTBE, remediation can occur at a reasonable rate.

\section{PHYTOREMEDIATION IS A USEFUL OPTION}

The above-mentioned studies and the work reported by Zhang [54] showed that plants such as alfalfa could grow in the presence of significant concentrations of MTBE $(>100 \mathrm{ppm})$ and serve as a means to withdraw MTBE-contaminated water. This can be useful as a means to control plume migration in climates where potential evapotranspiration exceeds precipitation. More recently, Hong et al. [21] successfully applied hybrid poplars as a means to control a plume of MTBE at a site where potential evapotranspiration $(\sim 150 \mathrm{~cm} / \mathrm{yr})$ does not greatly exceed precipitation $(\sim 100 \mathrm{~cm} / \mathrm{yr})$. In this instance a relatively tight clay layer covered the contaminated sandy aquifer, so that little precipitation could recharge the aquifer as the plants extracted the water. A paved parking lot could serve the same purpose at a site such as a gasoline station. By use of ${ }^{14} \mathrm{C}$-labeled MTBE, Hong et al. [21] documented that little MTBE metabolism occurs within the tree; most input MTBE departs to the atmosphere unchanged.

Because of the significant amount of water that plants remove from the soil and groundwater, the location of the water table may be lowered allowing aerobic biodegradation to occur in additional parts of the site. Vegetation has the potential to enhance the rate of disappearance of MTBE at contaminated sites through evapotranspiration and biodegradation. The MTBE that passes to the atmosphere is readily trans- formed through gas-phase reactions that occur when light is present. The half-life of MTBE in the atmosphere may be as short as 3 days because of hydroxyl radials $\left(\mathrm{OH}^{-}\right)$that participate in chemical transformations that occur $[58,59]$.

Research on phytoremediation of MTBE has recently been reviewed [58]. Investigations with hybrid poplars and alfalfa have shown that MTBE passes through both poplars and alfalfa to the atmosphere as the process of evapotranspiration brings MTBE contaminated water into the plant.

\section{CONCLUSIONS}

There are now sufficient examples of MTBE bioremediation to ensure that it is feasible under many conditions. Several pilot tests and limited field applications show that biodegradation is often significant at sites where monitored natural attenuation is the remediation process. In the past decade, the number of species that degrade MTBE, and the reported rates of biodegradation, have increased significantly. Until further work is done it will not be possible to determine the extent to which bioaugmentation may be beneficial at field sites. Both aerobic and anaerobic strategies may be applicable; however, aerobic biodegradation rates are larger. Vegetation is generally beneficial at sites where monitored natural attenuation is used.

\section{ACKNOWLEDGMENTS}

The research described herein was partially supported by the U.S. EPA under an assistance agreement R-82550 to the Great Plains-Rocky Mountain Hazardous Substance Research Center for Regions 7 and 8 under projects 94-27 and 98-3. It has not been submitted to the EPA for peer review and therefore may not necessarily reflect views of the agency, and no official endorsement should be inferred. The Center for Hazardous Substance Research also provided partial funding. This is contribution 04-068-J of the Kansas Agricultural Experiment Station.

\section{LITERATURE CITED}

1. Amerson, I., \& Johnson, R.L. (2003). Natural gradient tracer test to evaluate natural attenuation of MTBE under anaerobic conditions, Ground Water Monitoring and Remediation, 23, 54-61.

2. American Petroleum Institute (API). 2003. http:// www.mtberesource.com (Accessed 5 December 2003).

3. Baker, K.M., Butler, B.J., \& Barker, J.F. 2002. Field test of cometabolic remediation system for MTBE, cited in Chemical Abstracts, CAPLUS AN 2003: 336664.

4. Basagaoglu, H., Chung, E.E., Gandhi, D., Scow, K.M., McCoy, B.J., \& Ginn, T.R. (2003). Rate parameters for methyl tert-butyl ether biodegradation via a radial diffusion model, Journal of Environmental Engineering, 129, 565-570.

5. Bradley, P.M., Landmeyer, J.E., \& Chapelle, F.H. (1999). Aerobic mineralization of MTBE and tertbutyl alcohol by stream-bed sediment microorganisms, Environmental Science and Technology, 33, 1877-1879. 
6. Bradley, P.M., Chapelle, F.H., \& Landmeyer, J.E. (2001a). Methyl tert-butyl ether mineralization in surface-water sediment microcosms under denitrifying conditions, Applied Environmental Microbiology, 67, 1975-1978.

7. Bradley, P.M., Chapelle, F.H., \& Landmeyer, J.E. (2001b). Effect of redox conditions on MTBE biodegradation in surface water sediments, Environmental Science and Technology, 35, 4643-4647.

8. Bradley, P.M., Landmeyer, J.E., \& Chapelle, F.H. (2001). Widespread potential for microbial MTBE degradation in surface-water sediments, Environmental Science and Technology, 35, 658-662.

9. Bruns, M.A., Hanson, J.R., Mefford, J., \& Scow, K.M. (2001). Isolate PM1 populations are dominant and novel methyl tert-butyl ether-degrading bacteria in compost biofilter enrichments, Environmental Microbiology, 3, 220-225.

10. Callender, T., \& Davis, L.C. 2001. Environmental behavior of methyl tert-butyl ether: a study of Henry's law constant and the dispersion of MTBE through river bottom sand and soil. In Proceedings of the 2001 Conference on Environmental Research, Kansas State University, Manhattan, KS (pp 137-146), http://www.engg.ksu.edu/HSRC/ (Accessed 5 December 2003).

11. Dupasquier, D., Revah, S., \& Auria, R. (2002). Biofiltration of methyl tert-butyl ether vapors by cometabolism with pentane: modeling and experimental approach, Environmental Science and Technology, 36, 247-253.

12. Energy Information Administration (EIA). 2003. Status and impact of state MTBE bans, Washington, DC: U.S. Department of Energy, March 2003 revision, http://www.tonto.eia.doe.gov/FTPROOT/service/ mtbe.pdf (Accessed 5 December 2003).

13. Environmental Working Group, EWG.ORG. 2003. http://www.ewg.org/reports/withknowledge/index. php (Accessed 5 December 2003).

14. Fayolle, F., Vandecasteele, J.-P., \& Monot, F. (2001). Microbial degradation and fate in the environment of methyl tert-butyl ether and related fuel oxygenates, Applied Microbiology and Biotechnology $56,339-349$.

15. Finneran, K.T., \& Lovley, D.R. (2001). Anaerobic degradation of methyl tert-butyl ether (MTBE) and tert-butyl alcohol, Environmental Science and Technology, 35, 1785-1790.

16. Fiorenza, S., Suarez, M.P., \& Rifai, H.S. (2002). MTBE in groundwater: status and remediation, Journal of Environmental Engineering, 128, 773781.

17. Fortin, N.Y., Morales, M., Nakagawa, T., Focht, D.D., \& Deshusses, M.A. (2001). Methyl tert-butyl ether (MTBE) degradation by a microbial consortium, Environmental Microbiology, 3, 407-416.

18. Francois, A., Mathis, H., Godfroy, D., Piveteau, P., Fayolle, F., \& Monot, F. (2002). Biodegradation of methyl tert-butyl ether and other fuel oxygenates by a new strain, Mycobacterium austroafricanum IFP 2012, Applied Environmental Microbiology, 68, $2754-2762$.

19. Hanson, J.R. Ackerman, C.E., \& Scow, K.M. (1999).
Biodegradation of methyl tert-butyl ether by a bacterial pure culture, Applied Environmental Microbiology, 65, 4788-4782.

20. Hatzinger, P.B., McClay, K., Vainberg, S., Tugusheva, M., Condee, C.W., \& Steffan, R.J. (2001). Biodegradation of methyl tert-butyl ether by a pure bacterial culture, Applied Environmental Microbiology, 67, 5601-5607.

21. Hong, M.S., Farmayan, W.F., Dortch, I.J., Chiang, C.Y., McMillan, S.K., \& Schnoor, J.L. (2001). Phytoremediation of MTBE from a groundwater plume, Environmental Science and Technology, 35, 1231-1239.

22. Hristova, K., Gebreyesus, B., Mackay, D., \& Scow, K.M. (2003). Naturally occurring bacteria similar to the methyl tert-butyl ether (MTBE)-degradient strain PM1 are present in MTBE-contaminated groundwater, Applied Environmental Microbiology, 69, 2616-2623.

23. Hurt, K., Wilson, J., Beck, F., \& Cho, J. (1999). Anaerobic biodegradation of MTBE in a contaminated aquifer. In B. Alleman \& A. Leeson (Eds.), Natural attenuation of chlorinated solvents, petroleum hydrocarbons, and other organic compounds (Volume 1, pp. 103-108), Columbus, OH: Battelle Press.

24. Jacobs, J., Guertin, J., \& Herron, C. (Eds.). (2001). MTBE: effects on soil and groundwater resources, Boca Raton, FL: Lewis Publishers.

25. Kane, S.R., Beller, H.R., Legler, T.C., Koester, C.J., Pinkart, H.C., Halden, R.U., \& Happel, A.M. (2001). Aerobic biodegradation of methyl tert-butyl ether by aquifer bacteria from leaking underground storage tank sites, Applied Environmental Microbiology, 67, 5824-5829.

26. Keller, A., Froines, J., Koshland, C., Reuter, J., Suffet, I., \& Last, J. (1998). Health and environmental assessment of MTBE. Report to the Governor and Legislature of the State of California as Sponsored by SB521, Volume 1: Summary and Recommendations, 1998; http://www.tsrtp.ucdavis.edu/mtberpt/ vol1.pdf (Accessed 15 June 2003).

27. Keller, A.A., Sandall, O.C., Rinker, R.G., Mitani, M.M., Bierwagen, B., \& Snodgrass, M.J. (2000). An evaluation of physicochemical treatment technologies for water contaminated with MTBE, Ground Water Monitoring and Remediation, 20, 114-126.

28. Kern, E.A., Veeh, R.H., Langner, H.W., Macur, R.E., \& Cunningham, A.B. (2002). Characterization of methyl tert-butyl ether-degrading bacteria from a gasoline-contaminated aquifer, Bioremediation Journal, 6, 113-124.

29. Kharoune, M., Pass, A., \& Labeled, J.R. (2001). Aerobic biodegradation of an oxygenate mixture: MTBE, MTBE and TAME in an upflow fixed-bed reactor, Water Research, 35, 1665-1674.

30. Kinner, N.E. (2001). Fate, transport and remediation of MTBE, Testimony before the United States Senate Committee on Environment and Public Works, http://www.asce.org/pdf/kinnertestimony. pdf (Accessed 5 December 2003).

31. Landmeyer, J.E., Chapelle, F.H., Herlong, H.H., \& Bradley, P.M. (2001). Methyl tert-butyl ether biodeg- 
radation by indigenous aquifer microorganisms under natural and artificial oxic conditions, Environmental Science and Technology, 35, 1118-1126.

32. Magar, V.S., Gibbs, J.T., O’Reilly, K.T., Hyman, M.R., \& Leeson, A. (Eds.). (2001). Bioremediation of MTBE, alcohols and ethers, Columbus, OH: Battelle Press.

33. Methanol Institute. (2001). Water quality impacts of MTBE: an update since the release of the UC report, prepared by Malcolm Pirnie Inc., http:// www.methanol.org/pdf/UCReportUpdate.pdf (Accessed 15 June 2003).

34. Mo, K., Lora, C.O., Wanken, A.E., Javanmardian, M., Yang, X., \& Kulpa, C.F. (1997). Biodegradation of methyl tert-butyl ether by pure bacterial cultures, Applied Microbiology and Biotechnology, 47, 69-72.

35. Moreels, D., Bastiaens, L., Merclox, R., Ollevier, F., Diels, L., \& Springael, D. (2001). Evaluation of intrinsic MTBE biodegradation potential in MTBEcontaminated soils, Medical Facility Landbouw University of Gent, 66, 187-190.

36. National Ground Water Association (NGWA). (2003). Conference on MTBE: assessment, remediation and public policy, http://www.nationalgroundwater.org/pdf/mtbebrochure.pdf (Accessed 5 December 2003).

37. New England Interstate Water Pollution Control Commission (NEIWPCC). (2001). A survey of state experiences with MTBE contamination at LUST sites, http://www.neiwpcc.org/mtbees.html (Accessed 5 December 2003).

38. Odencrantz, J.E. (1998). Implications of MTBE for intrinsic remediation of underground fuel tank sites, Journal of Remediation (The Journal of Environmental Cleanup, Technologies and Techniques) Summer, 7-16, http://www.tri-S.com/ publications.htm (Accessed 5 December 2003).

39. Peargin, T.R. (2001). Relative depletion rates of MTBE, benzene, xylene from smear zone nonaqueous phase liquid. In V.S. Magar, J.T. Gibbs, K.T. O'Reilly, M.R. Hyman, \& A. Leeson (Eds.), Bioremediation of MTBE, alcohols, and ethers (pp. 67-74), Columbus, OH: Battelle Press.

40. Prince, R.C. (2000). Biodegradation of methyl tertiary-butyl ether (MTBE) and other fuel oxygenates, Critical Reviews in Microbiology, 26, 163-178.

41. Robb, J., \& Moyer, E. (2001). Natural attenuation of dissolved benzene and MTBE-two case studies, In V.S. Magar, J.T. Gibbs, K.T. O'Reilly, M.R. Hyman, \& A. Leeson (Eds.), Bioremediation of MTBE, alcohols, and ethers (pp. 75-82), Columbus, OH: Battelle Press.

42. Salanitro, J.P., Spinnler, G.E., Maner, P.M., Tharpe, D.L., Pickle, D.W., Wisniewski, H.L., Johnson, P.C., \& Bruce, C. (2001). In situ bioremediation of MTBE using biobarriers of single or mixed cultures. In A. Leeson, B.C. Alleman, P.J. Alvarez, \& V.S. Magar (Eds.), Bioaugmentation, biobarriers and biogeochemistry (Volume 8, pp. 61-71), Columbus, OH: Battelle Press.

43. Schirmer, M., \& Barker, J.F. (1998). A study of the long-term MTBE attenuation in the Borden aquifer,
Ontario, Canada, Ground Water Monitoring and Remediation, 18, 113-122.

44. Schirmer, M., Butler, B.J., Church, C.D., Barker, J.F., \& Nadarajah, N. (2003). Laboratory evidence of MTBE biodegradation in Borden aquifer material, Journal of Contaminant Hydrology, 60, 229-249.

45. Seagren, E.A., \& Becker, J.G. (2002). Review of natural attenuation of BTEX and MTBE in groundwater, Practice Periodical of Hazardous, Toxic and Radioactive Waste Management, 6, 156-172.

46. Stavnes, S.A., Fleischman, J.J., Hunt, S., Goetz, J., Kemper, M., Roulier, M., Hristova, K., Scow, K., Knutson, K., Mahaffee, W.R., Slomczynski, D.J., Davis-Hoover, W.J. (2002). MTBE bioremediation with BioNets containing Isolite, PM1, solid oxygen source (SOS) or air. In A.R. Gavaskar \& A.S.C. Chen (Eds.), Remediation of chlorinated and recalcitrant compounds 2002 (pp. 990-997), Columbus OH: Battelle Press.

47. Steffan, R.J., Vainberg, S., Condee, C.W., McClay, K., \& Hatzinger, P. (2000). Biotreatment of MTBE with a new bacterial isolate. In G.B. Wickramanayake, A.R. Gavaskar, B.C. Alleman, \& V.S. Magar (Eds.), Bioremediation and phytoremediation of chlorinated and recalcitrant compounds (pp 165173), Columbus, OH: Battelle Press.

48. Streger, S.H., Vainberg, S., Dong, H., \& Hatzinger, P.B. (2002). Enhancing transport of Hydrogenophaga flava ENV735 for bioaugmentation of aquifers contaminated with methyl tert-butyl ether, Applied Environmental Microbiology, 68, 5571-5579.

49. United States Environmental Protection Agency (USEPA). (2002). Envirogen propane biostimulation technology for in-situ treatment of MTBE-contaminated ground water, EPA/600/R02/092, Ground Water and Ecosystems Restoration Research, Washington, DC: U.S. EPA, http://www.epa.gov/ada/ pubs/reports/600R02092.html (Accessed 5 December 2003).

50. Wilson, B.H., Shen, H., \& Pope, D. (2001). Cost of MTBE bioremediation. In V.S. Mager, J.T. Gibbs, K.T. O'Reilly, M.R. Hyman, \& A. Leeson (Eds.), Bioremediation of MTBE, alcohols, and ethers (pp. 129-136), Columbus, OH: Battelle Press.

51. Wilson, G.J., Richter, A.P., Suidan, M.T., \& Venosa, A.D. (2001). Aerobic biodegradation of gasoline oxygenases MTBE and TBA, Water Science and Technology, 43, 277-284.

52. Wilson, J.T., Cho, J.S., \& Vardy, J.A. (2000). Natural attenuation of MTBE in the subsurface under methanogenic conditions, U.S. Environmental Protection Agency Report, EPA/600/R-00/006, Washington, DC: Office of Research and Development.

53. Wilson, R., Scow, K.M., \& Mackay, D. (2002). In situ MTBE biodegradation supported by diffusive oxygen release, Environmental Science and Technology, 36, 190-199.

54. Zhang, Q. (1999). Phytoremediation of methyl tertbutyl ether (MTBE) in groundwater-experimental and modeling studies, Ph.D. Dissertation, Department of Chemical Engineering, Kansas State University, Manhattan, KS. 
55. Zhang, Q., Davis, L.C., \& Erickson, L.E. (2001). Transport of methyl tert-butyl ether through alfalfa plants, Environmental Science and Technology, 35, 725-731.

56. Zhang, Q., Davis, L.C., \& Erickson, L.E. (2001). Plant uptake of methyl tert-butyl ether (MTBE) from ground water, Practice Periodical of Hazardous, Toxic and Radioactive Waste Management, 5, $136-140$.

57. Zoeckler, J.R., Widdowson, M.A., \& Novak, J.T. (2003). Aerobic biodegradation of methyl tert-butyl ether in gasoline-contaminated aquifer sediments, Journal of Environmental Engineering, 129, 642-650.
58. Winnike-McMillan, S.K., Zhang, Q., Davis, L.C., Erickson, L.E., \& Schnoor, J.L. (2003). Phytoremediation of methyl tertiary-butyl ether. In S.C. McCutcheon \& J.L. Schnoor (Eds.), Phytoremediation: transformation and control of contaminants (pp. 805-828), New York: Wiley.

59. Squillace, P.J., Pankow, J.F., Korte, N.E., \& Zogorski, J.S. (1997). Review of the environmental behavior and fate of methyl tert-butyl ether, Environmental and Toxicological Chemistry, 16, 1836-1844.

60. Moyer, E.E., \& Kostecki, P.T. (2003). MTBE remediation handbook, Amherst, MA: Amherst Scientific Publishers. 